\title{
Seawater tolerance and morphological assessment of yearling sea trout (Salmo trutta L.)
}

\author{
Ilze Rutkovska $[$ - Ruta Medne $\cdot$ Santa Purvina
}

Received: 5 April 2019/Accepted: 20 August 2019/Published online: 30 August 2019

(C) The Author(s) 2019

\begin{abstract}
To study seawater tolerance and make a morphological assessment of yearling sea trout, their maturation and smoltification signs were estimated in two different fish rearing systems in Latvia,-in recirculating and flow-through system. For yearling sea trout (Salmo trutta L.), fish hypo-osmoregulatory ability was evaluated using seawater tolerance test, also fish morphological parameters were analyzed from January to May. April and May are months when smoltification occurs for wild sea trout in nature. Sea trout from recirculating system initially showed better growth, higher survival rate, and hypo-osmoregulatory ability, due to the elevated rearing water temperature. However, the situation completely changed in May when natural smoltification peaked and wild sea trout migration to the sea occurred-survival rate for yearling sea trout reared in recirculating system dropped to zero. Nevertheless, survival of fish from flow-through system increased, reaching 33\%. Furthermore, in flow-through systems, sea trout that survived had significantly lower condition factor, also silvering level was higher compared those who did not survive. Weight was not a useful factor for determination of sea trout smoltification. The most part of yearling sea trout did not smoltify at the age of 1 year and should be reared for one more year before release in natural watercourses foreseen for migration to the sea.
\end{abstract}

Keywords Morphology $\cdot$ Salmonids $\cdot$ Silvering $\cdot$ Smoltification $\cdot$ Chloride

\section{Introduction}

Latvia performs restocking of sea trout (Salmo trutta L.) to improve the natural salmonid resources adversely affected by hydroelectric power station cascade on the River Daugava and other anthropogenic factors. In climatic conditions common in Latvia, wild sea trout smolts start a migration to the Baltic Sea at the end of April, reaching the peak migration level in the first part of May, and lasts until the end of May (Briede and Kirjusina 2018).

Smoltification is a marginal metabolic process for anadromous salmonids, and it includes physiological, neuroendocrine and behavioral changes that allow the juvenile salmonid parr to adapt from fresh to saltwater

I. Rutkovska $(\bowtie) \cdot$ R. Medne

Faculty of Veterinary Medicine, Latvia University of Life Sciences and Technologies, K.Helmana iela 8, Jelgava 3004 , Latvia

e-mail: ilze.rutkovska@gmail.com

R. Medne $\cdot$ S. Purvina

Fish Resources Research Department, Institute of Food Safety, Animal Health and Environment BIOR, Daugavgrīvas iela 8, Riga 1048, Latvia 
(McCormick 2013). The first week in saltwater is crucial for the survival of salmonids. This is when high mortality rate can be seen among them, mainly due to predators, osmoregulatory challenges, and water pollution (McCormick 2013; McCallum et al. 2019). Besides, artificially reared salmonids' immunity is not as well developed as for wild salmonids (Zwollo 2018). By now, in Latvia, it has been considered that artificially reared yearling sea trout that have reached definite weight in April and May (15 g in accordance with the Restocking plan of fish resources 2017-2020) are smolts and can be released in natural watercourses. The set "smoltification weight" is not based on any research and that makes us consider whether this practice is correct. In a case of incorrect estimation of sea trout release time, the efficiency of restocking becomes significantly lower than it is expected.

There are several physiological factors which characterize smoltification-hormonal changes, different blood parameters, gill $\mathrm{Na}^{+} \mathrm{K}^{+}$-ATPase activity, seawater tolerance (Zaugg and McLain 1972), and several morphological parameters such as changes in condition factor (CF), body silvering, etc. (Quigley et al. 2006; McCormick et al. 2007).

The most important physiological change of the smoltification is the increase in hypo-osmoregulatory ability. It is due to anatomical changes in gills, kidney, and gut accompanied by physiological changes (McCormick 2013). For wild Atlantic salmon (Salmo salar) smolts, the first weeks in seawater are a crucial time when, due to the exposure to wild predators and osmoregulatory challenges, a high mortality rate can be observed. Saltwater causes increase in plasma ion level followed by tissue dehydration (Handeland et al. 1996). Smoltification ensures physiological changes in osmoregulation mechanisms of anadromous fish. In freshwater, there is active uptake of $\mathrm{NaCl}$ across gills and secretion of large amounts of dilute urine to counteract passive loss of ions and osmotic gain of water. However, in salt-water mechanisms change towards active drinking of water concurrent with secretion of minute amounts of iso-osmotic urine containing excess of divalent cations, and secretion of $\mathrm{NaCl}$ across the gills to counterbalance dehydration (Evans et al. 2005; Edwards and Marshall 2013). During smoltification, fresh-water chloride cells transform to seawater chloride cells with elevated gill $\mathrm{Na}^{+}, \mathrm{K}^{+}$-ATPase activity (Borgatti et al. 1992; McCormick 2013). To remove the excess $\mathrm{Na}^{+}$and $\mathrm{Cl}^{-}$ions from the blood, the gill $\mathrm{Na}^{+} \mathrm{K}^{+}$-ATPase pumps three $\mathrm{Na}^{+}$ions out and two $\mathrm{K}^{+}$ions in the chloride cells to set up an $\mathrm{Na}^{+}$gradient (Evans et al. 2005). The $\mathrm{Na}^{+}$gradient between blood and the chloride cells is used to bring $\mathrm{Cl}^{-}$into the cell. The $\mathrm{Cl}^{-}$then leaves the chloride cell through an apical chloride channel (Nilsen et al. 2007).

Studies have shown that smolts adapt to seawater better in higher temperature (Handeland et al. 2003, 2014). Nevertheless, purposefully raising the temperature in fish farm to promote fish growth can inhibit raising of gill $\mathrm{Na}^{+} \mathrm{K}^{+}$-ATPase activity (Ewing et al. 1979; Handeland et al. 2000).

Results of the previous research with Atlantic salmon indicated that there is a minimum fork length $(14 \mathrm{~cm})$ that must be reached to become a smolt (McCormick et al. 2014). However, results of experiments with sea trout done by Debowski et al. (2010) showed that length measurements taken in either autumn or winter in the first year of life cannot be used to predict the number of fish that will smoltify in the next spring.

The aim of the research was to evaluate the ability of yearling sea trout reared in Latvia to adapt to saltwater. The hypothesis of our study was to prove that the most part of yearling sea trout does not smoltify at 1-year age, and sea trout weight is not useful as an indicator of smoltification.

\section{Materials and methods}

The experimental studies were conducted in the Latvia University of Life Sciences and Technologies, Faculty of Veterinary Medicine, Institute of Food and Environmental Hygiene and in the Institute of Food Safety, Animal Health and Environment BIOR (further-Institute BIOR), Division of Inland Waters and Fish Restocking and Aquaculture Research and Education Center.

A total of 560 1-year-old sea trout from hatcheries located on three rivers of Latvia were examinedhatchery A (river Venta basin), hatchery B (river Gauja basin), and hatchery C (river Daugava basin). Eggs for hatching were obtained from wild spawners at the corresponding river of each hatchery. In hatchery A and B, fish were reared in flow-through systems, and in the hatchery $\mathrm{C}$, fish were reared in both flow-through and recirculating system $(\mathrm{CR})$. Fish were reared using ambient river water in tanks with $1.5 \mathrm{~m}$ diameter in natural photoperiod. Water flow rate was $0.16-0.18 \mathrm{~m} \mathrm{~s}^{-1}$. Stocking density in all hatcheries was approximately 
$30 \mathrm{~kg} \mathrm{~m}^{-3}$. Fish were fed with commercial pelleted feed Aller Futura of appropriate size and amount in accordance with manufacturer's recommendations (www.aller-aqua.com). Oxygen level and water temperature were measured three times per day (8:00 a.m., 2:00 p.m. and 8:00 p.m.). Oxygen level was maintained at 7-10 $\mathrm{mg} \mathrm{L}^{-1}$ throughout the entire rearing period.

The data of water temperature obtained from hatcheries showed that at the beginning of January, temperature in all three rivers and flow-through systems was almost equal, but in recirculating system, it was significantly higher (on average, $7.5^{\circ} \mathrm{C}$ ) than in flow-through systems (Table 1). Temperature difference between both systems remained stable until the beginning of April. River water warmed to $3.5-7.5^{\circ} \mathrm{C}$ on the second part of April; moreover, in May, water temperature reached $11-14{ }^{\circ} \mathrm{C}$. At the time of fish release (the beginning of May), water temperature in flow-through systems almost reached the level of water temperature in recirculating system.

All fish used in this research were planned to be released in natural watercourses in April or May of the same year. Once every 2 weeks starting from January to February and once a week in March and April and once in May, a group of sea trout $(n=10)$ of different sizes (4.9-43.6 g) was selected from each hatchery and transported to the Aquaculture research and education center. Transporting the fish required 1-2 h. Fish were transported in plastic bags placed on ice. The bags were filled with hatchery water (1/3) and oxygen (2/3). After arriving at the laboratory, sea trout were placed in $50 \mathrm{~L}$ tanks, supplied with water [temperature was adapted according to the water temperature in the hatchery (Table 1)] and exposed to natural photoperiod. Fish were acclimated for $48 \mathrm{~h}$ before the seawater challenge test was performed. The group of sea trout was not fed during the test.

Seawater tolerance was tested with $24 \mathrm{~h}$ saltwater challenge test (salinity $=30$ ). After $24 \mathrm{~h}$, plasma samples were taken from live fish caudal vein and placed in a portable refrigerator at $4{ }^{\circ} \mathrm{C}$ and immediately sent to the Laboratory of Pathology of the Institute BIOR for determination of chlorine ion concentration using indirect ion selective potentiometry. Analyzer ADVIA 1800 Siemens Healthcare Diagnostics was used (reagentChloride Siemens).

Both sea trout survived and those that did not survive during saltwater challenge test were assessed morphologically. Fish silvering was evaluated using scale from 0 to 4 (Birt and Green 1986, modified by Rutkovska and Medne 2015) (Table 2), and the body fork length (length from anterior-most part of the fish to the end of the median caudal fin rays) was measured and fish were weighed. Sea trout sex was recorded.

After the measurements were made, a CF was calculated by the following formula (Formula 1) (Berrill et al. 2006):

$$
\mathrm{CF}=\frac{W}{L^{3}} 100
$$

where $\mathrm{CF}$ - condition factor; $W$-fish weight, $\mathrm{g} ; L$-fork length, $\mathrm{cm}$.

Silvering indices were calculated by the following formula (Formula 2) (Medne 2011):

Table 1 Average water temperature in fish farms

\begin{tabular}{lcccc}
\hline Time period & \multicolumn{3}{l}{ Fish farm/rearing system } & \\
\cline { 2 - 5 } & A/flow-through & B/flow-through & C/flow-through & C/recirculating \\
\hline 1st half of January & $0.3 \pm 0.11$ & $0.3 \pm 0.14$ & $0.2 \pm 0.09$ & $8.1 \pm 0.06$ \\
2nd half of January & $0.2 \pm 0.07$ & $0.8 \pm 0.04$ & $0.8 \pm 0.07$ & $8.0 \pm 0.05$ \\
1st part of February & $0.2 \pm 0.03$ & $0.8 \pm 0.05$ & $0.3 \pm 0.04$ & $8.1 \pm 0.04$ \\
2nd half of February & $0.2 \pm 0.04$ & $0.7 \pm 0.05$ & $0.2 \pm 0.01$ & $8.0 \pm 0.04$ \\
1st half of March & $0.3 \pm 0.03$ & $0.8 \pm 0.05$ & $0.4 \pm 0.04$ & $8.0 \pm 0.05$ \\
2nd half of March & $0.3 \pm 0.17$ & $0.9 \pm 0.53$ & $1.0 \pm 0.22$ & $7.9 \pm 0.07$ \\
1st half of April & $0.6 \pm 0.84$ & $1.2 \pm 0.61$ & $0.3 \pm 1.10$ & $8.1 \pm 0.05$ \\
2nd half of April & $7.3 \pm 2.04$ & $3.5 \pm 1.29$ & $4.5 \pm 1.70$ & $8.7 \pm 0.42$ \\
1st half of May & $14.0 \pm 0.98$ & $11.4 \pm 0.21$ & $12.2 \pm 1.06$ & $15.9 \pm 1.32$ \\
Fish release & & & &
\end{tabular}


Table 2 Evaluation of silvering level

\begin{tabular}{ll}
\hline Scale & Description \\
\hline 0 & Parr. No signs of silvering, clearly visible parr marks \\
1 & Parr. Slightly silvery colour. Visible parr marks, some signs of silvering \\
2 & Smolt like Parr. (50\% silvering). Silvery colour and visible parr marks \\
3 & Smolt like Parr. (75\% silvering). Silvery colour and only slightly visible parr marks \\
4 & Smolt. Silvery colour, black fin margins. No visible parr marks \\
\hline
\end{tabular}

$$
I_{\mathrm{s}}=N^{-1} \sum_{n=0}^{5} n_{i} S_{i}
$$

where $I_{\mathrm{s}}$ - silvering index of fish group; $N$-number of investigated fish; $n$-number of fish in each silvering group; and $S$-silvering level in accordance with scale (Table 2).

Average and standard deviation (SD) was calculated for the data obtained. The $T$ test for comparison of two separate samples was used to compare parameters' differences between flow-through system and recirculating system in hatchery $C$, and differences between the sea trout that survived and sea trout that did not (Sokal and Rohlf 2000). Parametric tests were used, as variances were homogeneous and distribution was normal. ANOVA was used to test differences between parameters. Differences between the groups were considered statistically significant at $p<0.05$ and $p<0.01$.

\section{Results}

Yearling sea trout showed a very low survival rate during saltwater challenge test. There were only sporadic survival cases of sea trout from all hatcheries and both rearing systems during the first months of the study. From January until April, survival was higher in recirculating system, however, in May-in flow-through system. In May, survival in flow-through system increased for more than four times signalizing for fish adaptation to saline water (Fig. 1).

Overall, only $7.3 \%$ of sea trout survived during the saltwater challenge test (flow-through system-6.7\%, recirculating system-10.7\%). $47.5 \%$ of them were male and $52.5 \%$ were female. The highest surveillance

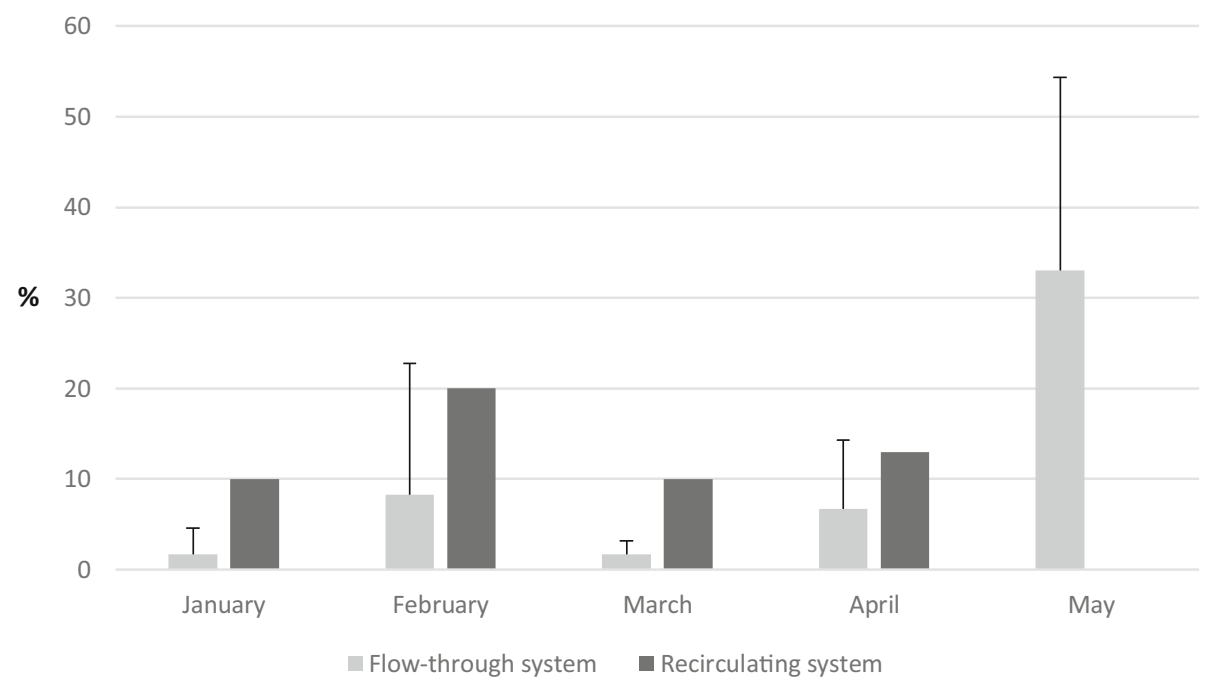

Fig. 1 Proportion of sea trout survived during saltwater challenge test, \% $(n=560)$ 
was observed in May for sea trout of flow-through system-33.0\%. At the same time, all fish from recirculating system in May died during the salt-water challenge test.

Mean plasma chloride concentration (Table 3) for sea trout from flow-through system exceeded $177 \mathrm{mmol} \mathrm{L}^{-1}$ in January and February. Starting from March chloride concentration slightly decreased, reaching $162 \mathrm{mmol} \mathrm{L}^{-1}$ in May. However, mean plasma chloride concentration for sea trout from recirculating system was quite stable from month to month. Since no sea trout survived from recirculating system in May, there are no data on plasma chloride concentration.

Morphological analysis of sea trout studied confirmed that morphological characteristics (weight, fork length, and CF) differ significantly $(p<0.01)$ between fish reared in flow-through and in recirculating system (Table 4). The only exception was silvering level that did not show significant difference $(p>0.05)$ between fish from both rearing systems.

When comparing morphological characteristics between sea trout that did and did not survive, we can see that there was no significant difference between weight and fork length $(p>0.05)$ in flow-through system, however, in recirculating system reared sea trout that survived were significantly longer than those that did not survive $(p<0.05)$ (Table 4). Nevertheless, CF for sea trout survived was significantly lower $(p<0.01)$ than $\mathrm{CF}$ for sea trout died in flow-through system. Furthermore, there was significant difference $(p<0.05)$ in flowthrough system between mean silvering level of sea trout survived and sea trout died.

\section{Discussion}

The high mortality during a saltwater challenge test indicated that the hypo-osmoregulatory ability of the major part of reared yearling sea trout were completely undeveloped. Results showed that the major part of fish from both rearing systems were not ready for migration to the sea. Although sea trout from recirculating system initially showed higher survival rates (even when they were not expected—in January and February), sea trout from flow-through systems demonstrated stable increase in hypo-osmoregulatory ability.

In the beginning of the research, survival rate of sea trout from flow-through systems was very low $(1.7 \%)$. Results of Urke et al. (2014) showed that plasma chloride concentration for Atlantic salmon smolts was from 137 to $143 \mathrm{mmol} \mathrm{L}^{-1}$ after saltwater challenge test. Similarly, Türker et al. (2004) also reported plasma chloride levels between 120 and $154 \mathrm{mmol} \mathrm{L}^{-1}$ in rainbow trout challenging seawater adaptation. In our research, the mean plasma chloride concentration for fish survived was very high in January and February (> $177.0 \mathrm{mmol} \mathrm{L}^{-1}$ ). However, gradually, the salt-water tolerance of sea trout improved, and at the end of experiment (in May), survival rate reached $33.0 \%$ and mean plasma chloride concentration decreased to $162.0 \mathrm{mmol} \mathrm{L}^{-1}$. Our results were in agreement with earlier findings of Türker et al. (2004) who reported declining peak levels of $153.9 \mathrm{mmol} \mathrm{L}^{-1}, 151.8 \mathrm{mmol} \mathrm{L}^{-1}$, and $142.9 \mathrm{mmol} \mathrm{L}^{-1}$ for plasma $\mathrm{Cl}^{-}$in 14,20 , and $30 \mathrm{~g}$ rainbow trout exposed to direct seawater transfer. Our results in the present study indicated that approximately $33 \%$ of yearling sea trout reared in flow-through system most likely smoltified at the 1-year age. The rest of sea trout should be reared for one more year to become smolts and to be able to migrate to the sea.

The situation with sea trout from recirculating system was different. Although fish from recirculating system showed better hypo-osmoregulatory ability (higher survival rate $10-20 \%$ and stable plasma chloride concentration 158.67-168.99 mmol L${ }^{-1}$ ) for the first 4 months of the research, a sudden drop in hypoosmoregulatory ability was experienced in May and no fish survived during salt-water challenge test then. While sea trout from flow-through systems met our expectations for timing to smoltify according to wild sea trout smoltification time, sea trout from recirculating system demonstrated something unexpected. These

Table 3 Mean plasma chloride concentration, $\mathrm{mmol} \mathrm{L}^{-1}(n=41)$

\begin{tabular}{llllll}
\hline Rearing system & January & February & March & April & May \\
\hline Flow-through & $>177.00$ & $>177.00$ & $172.39 \pm 2.56$ & $162.81 \pm 4.51$ & $162.00 \pm 5.78$ \\
Recirculating & $165.91 \pm 4.35$ & $164.92 \pm 3.87$ & $168.99 \pm 4.21$ & $158.67 \pm 3.68$ & $\mathrm{nd}^{\mathrm{a}}$ \\
\hline
\end{tabular}

${ }^{a}$ No data due to death of all the sea trout examined 
Table 4 Morphological characteristics of sea trout examined during the study from January to May $(n=560)$

\begin{tabular}{|c|c|c|c|c|}
\hline \multirow{2}{*}{$\begin{array}{l}\text { Morphological } \\
\text { parameter }\end{array}$} & \multicolumn{2}{|c|}{ Sea trout survived $(n=41)$} & \multicolumn{2}{|l|}{ Sea trout died $(n=519)$} \\
\hline & $\begin{array}{l}\text { Flow-through system } \\
(n=28)\end{array}$ & $\begin{array}{l}\text { Recirculating system } \\
(n=15)\end{array}$ & $\begin{array}{l}\text { Flow-through system } \\
(n=392)\end{array}$ & $\begin{array}{l}\text { Recirculating system } \\
(n=125)\end{array}$ \\
\hline \multicolumn{5}{|l|}{ Weight (g) } \\
\hline Mean $\pm \mathrm{SD}$ & $12.0 \pm 5.4^{\mathrm{a}}$ & $24.5 \pm 5.3^{\mathrm{a}}$ & $12.4 \pm 3.7^{\mathrm{a}}$ & $21.9 \pm 6.9^{\mathrm{a}}$ \\
\hline Range & $4.9-25.1$ & $10.7-32.2$ & $5.1-25.8$ & $9.4-43.6$ \\
\hline \multicolumn{5}{|c|}{ Fork length $(\mathrm{cm})$} \\
\hline Mean \pm SD & $10.5 \pm 1.8^{\mathrm{a}}$ & $13.1 \pm 1.4^{\mathrm{ad}}$ & $10.4 \pm 1.1^{\mathrm{a}}$ & $12.2 \pm 1.3^{\mathrm{ad}}$ \\
\hline Range & $7.5-13.9$ & $9.4-14.8$ & $7.8-13.6$ & $9.4-15.5$ \\
\hline \multicolumn{5}{|l|}{$\mathrm{CF}$} \\
\hline Mean \pm SD & $0.98 \pm 0.10^{\mathrm{ac}}$ & $1.10 \pm 0.15^{\mathrm{a}}$ & $1.07 \pm 0.13^{\mathrm{ac}}$ & $1.18 \pm 0.14^{\mathrm{a}}$ \\
\hline Range & $0.81-1.17$ & $0.87-1.32$ & $0.74-1.45$ & $0.85-1.55$ \\
\hline \multicolumn{5}{|l|}{ Silvering level } \\
\hline Mean \pm SD & $2.54 \pm 0.50^{\mathrm{d}}$ & $2.73 \pm 0.44$ & $2.27 \pm 0.69^{\mathrm{bd}}$ & $2.42 \pm 0.74$ \\
\hline Range & $2-3$ & $2-3$ & $0-3$ & $0-3$ \\
\hline
\end{tabular}

${ }^{a}$ Significant difference $p<0.01$ between rearing systems

${ }^{\mathrm{b}}$ Significant difference $p<0.05$ between rearing systems

${ }^{\mathrm{c}}$ Significant difference $p<0.01$ between sea trout survived and sea trout died in each rearing system

${ }^{\mathrm{d}}$ Significant difference $p<0.05$ between sea trout survived and sea trout died in each rearing system

results indicated that sea trout from recirculating system have better hypo-osmoregulatory ability in winter and early spring than they have at the time when normally smoltification occurs in nature [from the end of April until the middle May (Briede and Kirjusina 2018)].

The main differences between rearing circumstances in both rearing systems were water temperature and, possibly, the water quality. As the water for flow-through systems was obtained directly from rivers, water quality in these rearing systems could be quite variable over time, dependent from different external conditions. In recirculating system, the water quality could be quite stable, as water was obtained from underground resources.

The main influencing factor that could disrupt the natural biorhythm of sea trout could be the water temperature. Temperature together with photoperiod is a very important environmental factor controlling growth and development of juvenile salmonids. In natural environment, the annual cycle of temperature defines the growth potential and the age at which juvenile salmonids reach the minimum size for initiation of smoltification (Stefansson et al. 2008). Temperature also influences smoltification directly, by controlling the rate of physiological, morphological, and behavioral development (McCormick et al. 2000). While in the first 3 months of the research, the water temperature in flow-through systems was a little above $0{ }^{\circ} \mathrm{C}$ (Table 1 ), in the recirculating system, water temperature at the same time was approximately $8{ }^{\circ} \mathrm{C}$. Such a temperature is more optimal for sea trout growth, since it promotes fish feeding. Besides Handeland et al. (2004) estimated a period of approximately $350 \mathrm{~d}{ }^{\circ} \mathrm{C}$ between the onset of the smolt-related increase in gill $\mathrm{Na}^{+} \mathrm{K}^{+}$-ATPase activity of Atlantic salmon and the peak in enzyme activity. It means that the sea trout in recirculating system may had experienced smoltification peak earlier than sea trout in natural environment. However, once the fish could not reach sea water, it is possible that desmoltification occurred, which is accelerated by high and increasing fresh-water temperatures (Soivio et al. 1988).

Results indicated that mean weight, fork length, and $\mathrm{CF}$ of the sea trout from recirculating system were significantly higher $(p<0.01)$ than for sea trout from flow-through systems (Table 4). Research done by Debowski et al. (1999) showed that CF is useless as smoltification indicator. However, Quigley et al. (2006) found that $\mathrm{CF}$ of 1 and 2-year-old Atlantic salmon decreased during smoltification, but CF of 2-year-old sea trout increased during smoltification. Our results showed that sea trout that survived had significantly lower $(p<0.01)$ CF than sea trout that died in flow-through systems. Reduction of CF during smoltification is caused by a rapid decrease of the reserves of body lipids, especially triglycerides (Sheridan 1989). 
When analyzing silvering level, it can be seen that there is no significant difference between fish from recirculating system and fish from flow-through system. However, silvering level in flow-through system was significantly higher $(p<0.05)$ for sea trout that survived during experiment than for those that did not. Silvering level for sea trout that survived was 2 or 3 -there were no fish with level 0 or level 1 . However, silvering level for fish that died was from 0 to 3 . No fish reached a maximum silvering level 4 . These results coincide with the previous studies, showing that there are not as visible changes in sea trout, as they are for salmon during smoltification (Debowski et al. 1999). It could be connected to very intensive growth of sea trout during spring (Tanguy et al. 1994).

There could be seen silvering in 1-year-old sea trout in spring, but this parameter alone without other smoltification signs does not indicate smoltification.

If we analyze morphological parameters of "smolts" of the experiment, we can see that there are no morphological signs that can be used as smoltification indicators alone. Fish weight did not differ significantly between smolts and parrs. This indicates that weight is not a crucial factor for smoltification and intentional weight gain is not useful to promote smoltification. Even more, sea trout from flow-through systems with lower CF showed higher survival rate than those with higher CF. Although fork length differed significantly between parrs and smolts in recirculating system, it did not differ for sea trout in flow-through systems.

\section{Conclusions}

Despite the growth contributing circumstances in recirculating system, they do not promote smoltification of yearling sea trout. Nevertheless, hypo-osmoregulatory ability steadily develops for yearling sea trout reared in flow-through system. Although yearling sea trout with lower CF have better hypo-osmoregulatory ability than those with higher $\mathrm{CF}$, fish weight and fork length are not useful for determination of sea trout smolts. In summary, the most part of yearling sea trout do not smoltify in the 1-year age and need to be reared for at least one more year before release in natural watercourses.

Open Access This article is distributed under the terms of the Creative Commons Attribution 4.0 International License (http:// creativecommons.org/licenses/by/4.0/), which permits unrestricted use, distribution, and reproduction in any medium, provided you give appropriate credit to the original author(s) and the source, provide a link to the Creative Commons license, and indicate if changes were made.

\section{References}

Berrill IK, Porter MJR, Bromage NR (2006) The effects of daily ration on growth and smoltification in $0+$ and $1+$ Atlantic salmon (Salmo salar) parr. Aquaculture 257:470-481

Birt TP, Green JM (1986) Parr-smolt transformation in female and sexually mature male anadromous Atlantic salmon Salmo salar. Can J Fish Aquat Sci 43:680-686

Borgatti AR, Paliarani A, Ventrella V (1992) Gill $\left(\mathrm{Na}^{+}+\mathrm{K}^{+}\right)$-ATPase involvement and regulation during salmonid adaptation to salt water. Comput Biochem Physiol A 102:637-643

Briede I, Kirjusina M (2018) Zivis un vēži Latvijas akvakulturā. Bioloğija un slimības. Daugavpils Universitātes apgāds "Saule”, Daugavpils

Debowski P, Glogowski J, Dobosz S, Robak S (1999) Gill Na +, K + -ATPase activity and body silvering as indices of smoltification of hatchery-reared sea trout. Arch Pol Fish 7:245-256

Debowski P, Dobosz S, Grudniewska J, Kuzminski H (2010) Possibilities of using the length differentiation of hatchery sea trout, Salmo trutta L., parr to predict numbers of one-year smolts. Arch Pol Fish 18:51-58

Edwards SL, Marshall WS (2013) Principles and patterns of osmoregulation and euryhalinity in fishes. In: McCormick SD, Brauner CJ, Farrell AP (eds) Fish physiology. Euryhaline Fishes, vol 32. Academic Press, Amsterdam, pp 1-44

Evans DH, Piermarini PM, Choe KP (2005) The multifunctional fish gill: dominant site of gas exchange, osmoregulation, acidbase regulation, and excretion of nitrogenous waste. Physiol Rev 85:97-177

Ewing RD, Johnson SL, Pribble HJ, Lichatowich JA (1979) Temperature and photoperiod effects on gill (Na + K +)-ATPase activity in chinook salmon (Oncorhynchus tshawytscha). J Fish Res Board Can 36:1347-1353

Handeland SO, Jarvi T, Ferno A, Stefansson SO (1996) Osmotic stress, antipredator behaviour, and mortality of Atlantic salmon (Salmo salar) smolts. Can J Fish Aquat Sci 53:2673-2680

Handeland SO, Berge A, Björnsson BTh, Lie O, Stefansson SO (2000) Seawater adaptation by out-of-season Atlantic salmon (Salmo salar L.) smolts at different temperatures. Aquaculture 181:377-396 
Handeland SO, Björnsson BTh, Arnesen AM, Stefansson SO (2003) Seawater adaptation and growth of post-smolt Atlantic salmon (Salmo salar L.) of wild and farmed strains. Aquaculture 220:367-384

Handeland SO, Wilkinson E, Sveinsbo B, McCormick SD, Stefansson SO (2004) Temperature influence on the development and loss of seawater tolerance in two fast-growing strains of Atlantic salmon. Aquaculture 233:513-529

Handeland SO, Imsland AK, Nilsen TO, Ebbesson LOE, Hosfeld CD, Pedrosa C, Toften H, Stefansson SO (2014) Osmoregulation in Atlantic salmon Salmo salar smolts transferred to seawater at different temperatures. J Fish Biol 85:1163-1176

McCallum ES, Sundelin A, Fick J, Alanara A, Klaminder J, Hellstrom G, Brodin T (2019) Investigating tissue bioconcentration and the behavioural effects of two pharmaceutical pollutants on sea trout (Salmo trutta) in the laboratory and field. Aquat Toxicol 207:170-178

McCormick SD (2013) Smolt physiology and endocrinology. In: McCormick SD, Farrel AP, Brauner CJ (eds) Fish physiology, vol 32. Academic Press, Amsterdam, pp 199-251

McCormick SD, Moriyama S, Björnsson BT (2000) Low temperature limits photoperiod control of smolting in Atlantic salmon through endocrine mechanisms. Am J Physiol 278:R1352-R1361

McCormick SD, Shrimpton JM, Moriyama S, Björnsson BT (2007) Differential hormonal responses of Atlantic salmon parr and smolt to increased day length: a possible developmental basis for smolting. Aquaculture 273:337-344

McCormick SD, Haro A, Lerner DT, O’Dea MF, Regish AM (2014) Migratory patterns of hatchery and stream-reared Atlantic salmon Salmo salar smolts in the Connecticut River, U.S.A. J Fish Biol 85:1005-1022

Medne R (2011) Research of clinical signs and etiological factor of salmon fin necrosis, Dissertation, Latvia University of Life Sciences and Technologies

Nilsen TO, Ebbesson LOE, Madsen SS, McCormick SD, Andersson E, Björnsson BTh, Prunet P, Stefansson SO (2007) Differential expression of gill $\mathrm{Na}+, \mathrm{K}+$-ATPase $\alpha$ - and $\beta$-subunits, $\mathrm{Na}+, \mathrm{K}+, 2 \mathrm{Cl}$ - cotransporter and CFTR anion channel in juvenile anadromous and landlocked Atlantic salmon Salmo salar. J Exp Biol 210:2885-2896

Quigley DTG, Harvey MJ, Hayden TJ, Dowling C, O'Keane MP (2006) A comparative study of smoltification in sea trout (Salmo trutta L.) and Atlantic salmon (Salmo salar L.): sea water tolerance and thyroid hormone titres. Biol Environ Proc R Irish Acad 106:35-47

Rutkovska I, Medne R (2015) Morphological changes in artificially reared one year old sea trout (Salmo trutta L.) during spring. Research for rural development. Annual 21st international scientific conference proceedings, vol 1, Jelgava 13-15.05.2015, Latvia University of Life Sciences and Technologies, Jelgava, pp 189-193

Sheridan MA (1989) Alterations in lipid metabolism accompanying smoltification and seawater adaptation of salmonid fish. Aquaculture 82:191-203

Soivio A, Virtanen E, Muona M (1988) Desmoltification of heat-accelerated Baltic salmon (Salmo salar) in brackish water. Aquaculture 71:89-97

Sokal RR, Rohlf FJ (2000) Biometry: the principles and practice of statistics in biological research, 3rd edn. W.H Freeman and company, New York

Stefansson SO, Björnsson BT, Ebbesson LO, McCormick SD (2008) Smoltification. In: Finn RN, Kapoor BG (eds) Fish larval physiology. NH: Science Publishers, EnfieldNH, pp 639-681

Tanguy JM, Ombredane D, Bagliniere JL, Prunet P (1994) Aspects of parr-smolt transformation in anadromous and resident forms of brown trout (Salmo trutta) in comparison with Atlantic salmon (Salmo salar). Aquaculture 121:51-63

Türker A, Ergün S, Yigit M (2004) Changes in blood ion levels and mortality rates in different sized Rainbow trout (Onchorhynchus mykiss) following direct transfer to sea water. Isr J Aquac 56(1):51-58

Urke HA, Arnekleiv JV, Nilsen TO, Nilssen KJ, Rønning L, Ulvund JB, Kristensen T (2014) Long-term hypo-osmoregulatory capacity in downstream migrating Atlantic salmon Salmo salar L. smolts. J Fish Biol 85:1131-1144

Zaugg WW, McLain LR (1972) Changes in gill adenosine-triphosphatase activity associated with parr-smolt transformation in steelhead trout, coho, and spring Chinook salmon. J Fish Res Board Can 29:161-171

Zwollo P (2018) The humoral immune system of anadromous fish. Dev Comp Immunol 80:24-33

\section{Publisher's Note}

Springer Nature remains neutral with regard to jurisdictional claims in published maps and institutional affiliations. 